\title{
Long-term and interdisciplinary research on forest ecosystem functions: challenges at Takayama site since 1993
}

Published online: 5 March 2015

(C) The Ecological Society of Japan 2015

\section{Editorial}

Forest ecosystems cover approximately $30 \%$ of the terrestrial area of the Earth, and are expected to play crucial roles in regulating our environments including biodiversity and atmospheric $\mathrm{CO}_{2}$ concentration. As the structure and functions of the forest ecosystems are consists of multiple interactions of organisms, soil chemistry and meteorological conditions, which are quite variable in time and space, challenges to understand their processes and resulting dynamics of the functions have been made by various scientific disciplines/techniques such as ecology (including ecophysiology and biogeochemistry), hydrology, micrometeorology, simulation models and remote sensing.

This research has focused particularly on carbon, which is one of the "common" elements of ecological processes involved in ecosystems such as photosynthesis, respiration, and biomass growth, and of the interaction between the atmosphere and ecosystems, as the carbon cycle regulates biological aspects of ecosystems and hence determines the exchange of $\mathrm{CO}_{2}$ between the atmosphere and ecosystems. In recent decades, the carbon cycle and budget have been the central theme of environmental sciences by reflecting the ongoing climate change partly due to the rise in atmospheric $\mathrm{CO}_{2}$. In order to achieve deeper understanding of the dynamics of the structure and functions of forest ecosystems over time and space, it is essential to conduct investigations on (1) the detailed ecological processes in the carbon cycle, (2) their interactions with the climate, (3) integrated analysis of ecological and meteorological process,

H. Muraoka ( $₫) \cdot$ T. M. Saitoh

Gifu University, Gifu, Japan

E-mail: muraoka@green.gifu-u.ac.jp

S. Nagai

Japan Agency for Marine-Earth Science and Technology,

Yokohama, Japan and (4) observations of such structure and functions over time and space.

This special issue involves such multidisciplinary and long-term challenges at the "Takayama site" (Fig. 1) during the last 20 years since 1993, which is located on a mountainous region in central Japan. The site mainly consist of a cool-temperate deciduous broadleaf forest (TKY) and an evergreen coniferous forest (TKC), which are part of the AsiaFlux (http://www.asiaflux.net/) and Japan Long-Term Ecological Research (JaLTER, http://www.jalter.org/) networks. The history of the Takayama site (Fig. 2) was initiated by the long-term observation of $\mathrm{CO}_{2}$ exchange between the atmosphere and the deciduous forest, and ecological research for the carbon cycle processes in the forest, by numbers of scientists and students from several research institutes and universities (Saigusa et al. 2005; Yamamoto and Koizumi 2005; Ohtsuka et al. 2007, 2009, 2010). Efforts also have been made to link ecology, micrometeorology, modeling and remote sensing to explore the multi-scale investigations of the ecosystems and surrounding landscape, and this initiative is called "Satellite Ecology (SATECO)" (Muraoka and Koizumi 2009) which is now one of the interdisciplinary initiatives for cross-scale observation of ecosystems and for biodiversity-ecosystem-climate change observations in the Biodiversity Observation Network in Japan and in AsiaPacific (J-BON, AP-BON; Muraoka et al. 2012). An open-minded research policy at the Takayama site then enabled us to establish international networks for education and research in terrestrial ecosystems among Japan, South Korea and China, as well as collaborative activity between Japan and Germany for mountainous forest and landscape research under climate change.

As part of the results of our challenging efforts to achieve the multidisciplinary approach and collaborations, we could publish the following articles in this special issue. The reviews provide overview and challenges at the Takayama site by model integration (Ito et al. 2015) and our vision of sensor and site network for phenology observation (Nasahara and Nagai 2015). 


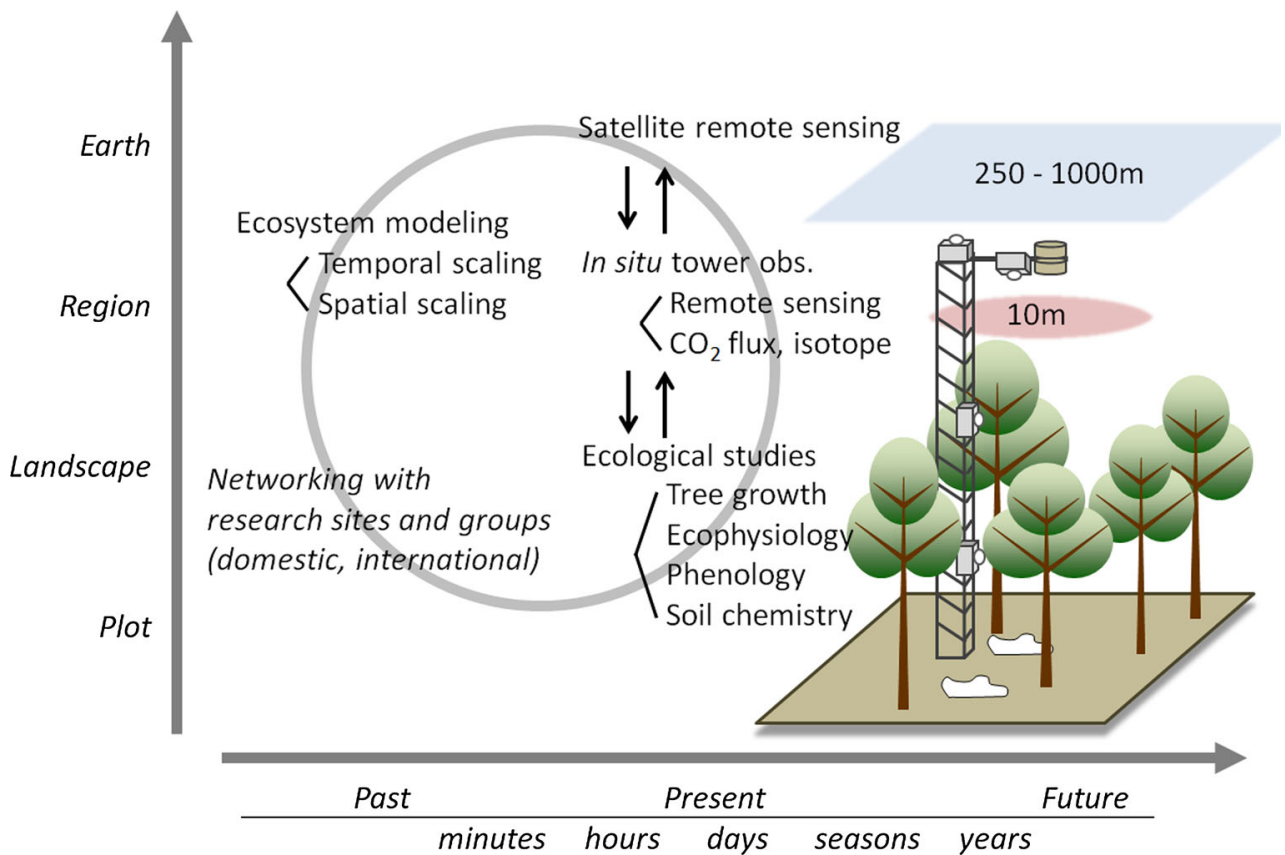

Fig. 1 Multidisciplinary research and networking at the Takayama site to explore cross-scale mechanisms and consequences of forest and landscape structure and functions

\section{Takayama chronicle}

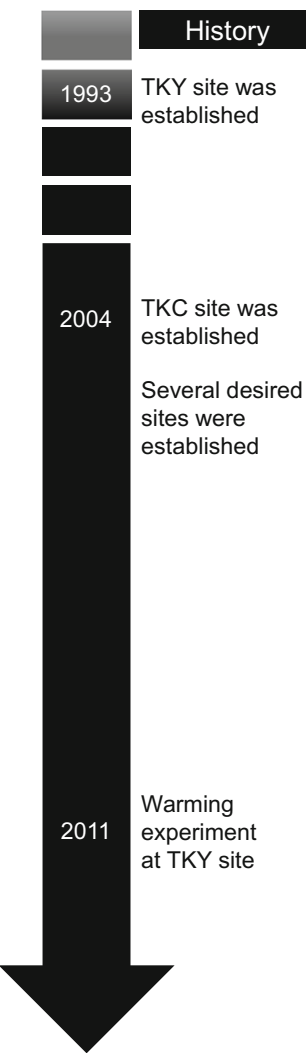

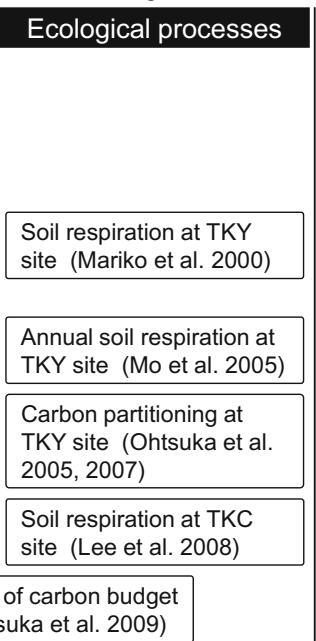

Carbon partitioning at grassland, young forest, and TKC sites (Dhital et al. 2010; Ohtsuka et al. 2010; Yashiro et al. 2010)

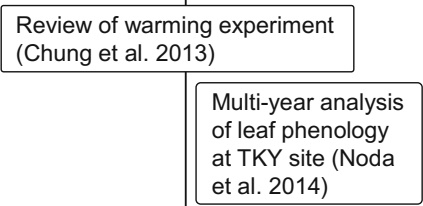

Atmospheric $\mathrm{CO}_{2}$ at et al. 1997)

Carbon budget at TKY 1999)

Inter-annual variation of carbon budget at al. 2005)

$\mathrm{CO}_{2}$ and its isotop TKY site (Mur et al. 2010)

Carbon budget at TKC site (Saitoh et al. 2010)
Ecosystem Model

Plant physiology

\section{PEN}

Photosynthetic and structural

characteristics at

TKY site (Muraoka et al. 2005)
Carbon budget at TKY site (Ito et al. 2005)

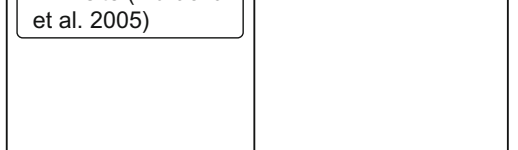

tablishment of Phenological Eyes Network (PEN)

(Nishida 2007)

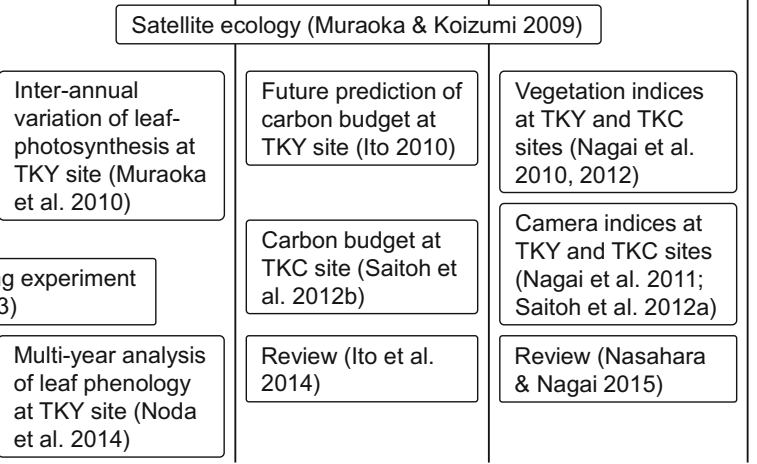

Fig. 2 Brief history of studies conducted at the Takayama site in the last 20 years. Note that the list covers part of the efforts made at the site 
Ecological studies on carbon cycle of forest ecosystems have been developed by detailed measurements of tree biomass growth and soil carbon dynamics (Kishimoto et al. 2015; Matsushita et al. 2015). Challenges have been also made for revealing soil microbial components in adjacent grasslands (Yoshitake et al. 2015) and to measure the soil structure by MRI (Tomotsune et al. 2015). Leaf and canopy ecophysiological characteristics which are tightly linked with ecosystem productivity in the Takayama site (Noda et al. 2015), atmospheric approach to reveal the temporal changes in carbon exchange between the atmosphere and forests (Ishidoya et al. 2015), and model analyses to clarify the functional contribution of leaf and canopy phenology on forest carbon balance under current and future conditions (Saitoh et al. 2015) or to evaluate the ecosystem services in the regional scale (Ruidisch et al. 2015).

Beside these achievements the research has also been made for soil biogeochemistry with respect to the carbon and nitrogen dynamics, ecophysiological role of tree sapflow and transpiration in forest water cycle, open field warming experiments on tree canopy photosynthesis and soil carbon dynamics, 'allocation flux' of carbon beginning from photosynthetic absorption to biomass growth and respiratory fluxes in plants and soil, and the cross-scale consequences of canopy phenology and its functions between stand and landscape scale on the mountainous area. As the integrative efforts by these studies, prediction of future changes in the carbon cycle and resulting budget, and more effective use of satellite remote sensing will be achieved shortly.

We will be grateful if the articles can provide valuable knowledge and information to the colleagues in related research field, and can bridge multiple research disciplines for further networking among the scientists and research sites for future studies.

Acknowledgments The Takayama research community appreciates supports gained by the Takayama field station staff (Mr. K. Kurumado and others) of Gifu University and related observation networks. We thank Ecological Research and its editor-in-chief (Dr. A. Kume), an associate editor-in-chief (Dr. T. Kumagai), the secretariat of the editorial office (Ms. Y. Aoshima), many reviewers, and Ecological Society of Japan, for their supports to realize this special issue.

\section{References}

Chung H, Muraoka H, Nakamura M, Han S, Muller O, Son Y (2013) Experimental warming studies on tree species and forest ecosystems: a literature review. J Plant Res 126:447-460. doi: 10.1007/s10265-013-0565-3

Dhital D, Yashiro Y, Ohtsuka T, Noda H, Shizu Y, Koizumi H (2010) Carbon dynamics and budget in a Zoysia japonica grassland, central Japan. J Plant Res 123:519-530. doi: 10.1007/s10265-009-0289-6

Ishidoya S, Murayama S, Kondo H, Saigusa N, Kishimoto-Mo AW, Yamamoto $\mathrm{S}$ (2015) Observation of $\mathrm{O}_{2}: \mathrm{CO}_{2}$ exchange ratio for net turbulent fluxes and its application to forest carbon cycles. Ecol Res. doi:10.1007/s11284-014-1241-3
Ito A (2010) Changing ecophysiological processes and carbon budget in East Asian ecosystems under near-future changes in climate: implications for long-term monitoring from a processbased model. J Plant Res 123:577-588. doi:10.1007/s10265009-0305-x

Ito A, Saigusa N, Murayama S, Yamamoto S (2005) Modeling of gross and net carbon dioxide exchange over a cool-temperate deciduous broad-leaved forest in Japan: analysis of seasonal and interannual change. Agric For Meteorol 134:122-134. doi: 10.1016/j.agrformet.2005.11.002

Ito A, Saitoh TM, Sasai T (2015) Synergies between observational and modeling studies at the Takayama site: toward a better understanding of processes in terrestrial ecosystems. Ecol Res. doi:10.1007/s11284-014-1205-7

Kishimoto-Mo AW, Yonemura S, Uchida M, Kondo M, Murayama M, Koizumi H (2015) Contribution of soil moisture to seasonal and annual variation of soil $\mathrm{CO}_{2}$ efflux in a humid cool-temperate oak-birch forest in central Japan. Ecol Res. doi: 10.1007/s11284-015-1254-6

Lee M-S, Lee J-S, Koizumi $\mathrm{H}$ (2007) Temporal variation in $\mathrm{CO}_{2}$ efflux from soil and snow surfaces in a Japanese cedar (Cryptomeria japonica) plantation, central Japan. Ecol Res 23:777-785. doi:10.1007/s11284-007-0439-Z

Mariko S, Nishimura N, Mo W, Matsui Y, Kibe T, Koizumi H (2000) Winter $\mathrm{CO}_{2}$ flux from soil and snow surfaces in a cooltemperate deciduous forest, Japan. Ecol Res 15:363-372. doi: 10.1046/j.1440-1703.2000.00357.x

Matsushita K, Tomotsune M, Sakamaki Y, Koizumi H (2015) Effects of management treatments on the carbon cycle of a cooltemperate broad-leaved deciduous forest and its potential as a bioenergy source. Ecol Res. doi:10.1007/s11284-014-1234-2

Mo W, Lee M-S, Uchida M, Inatomi M, Saigusa N, Mariko S, Koizumi H (2005) Seasonal and annual variations in soil respiration in a cool-temperate deciduous broad-leaved forest in Japan. Agric For Meteorol 134:81-94. doi:10.1016/j.agrformet. 2005.08.015

Muraoka H, Koizumi H (2005) Photosynthetic and structural characteristics of canopy and shrub trees in a cool-temperate deciduous broadleaved forest: implication to the ecosystem carbon gain. Agric For Meteorol 134:39-59. doi:10.1016/j. agrformet.2005.08.013

Muraoka H, Koizumi H (2009) "Satellite Ecology" for linking ecology, remote sensing and micrometeorology from plot to regional scales for ecosystem structure and function study. J Plant Res 122:3-20. doi:10.1007/s10265-008-0188-2

Muraoka H, Saigusa N, Nasahara KN, Noda H, Saitoh TM, Nagai S, Murayama S, Koizumi H (2010) Effects of seasonal and interannual variations in leaf photosynthesis and canopy leaf area index on gross primary production of a cool-temperate deciduous broadleaf forest in Takayama, Japan. J Plant Res 123:563-576. doi:10.1007/s10265-009-0270-4

Muraoka H, Ishii R, Nagai S, Suzuki R, Motohka T, Noda HM, Hirota M, Nasahara KN, Oguma H, Muramatsu K (2012) Linking remote sensing and in situ ecosystem/biodiversity observations by "Satellite Ecology". In: Nakano S, Yahara T, Nakashizuka T (eds) The biodiversity observation network in the Asia-Pacific region: toward further development of monitoring. Ecological Research Monographs, Springer, Japan, pp 277-308. doi:10.1007/978-4-431-54032-8_21

Murayama S, Takamura C, Yamamoto S, Saigusa N, Morimoto S, Kondo H, Nakazawa T, Aoki S, Usami T, Kondo M (2010) Seasonal variations of atmospheric $\mathrm{CO}_{2}, \delta^{13} \mathrm{C}$, and $\delta^{18} \mathrm{O}$ at a cool temperate deciduous forest in Japan: influence of Asian monsoon. J Geophys Res 115. doi:10.1029/2009jd013626

Nagai S, Saigusa N, Muraoka H, Nasahara KN (2010) What makes the satellite-based EVI-GPP relationship unclear in a deciduous broad-leaved forest? Ecol Res 25:359-365. doi: 10.1007/s11284-009-0663-9

Nagai S, Maeda T, Gamo M, Muraoka H, Suzuki R, Nasahara KN (2011) Using digital camera images to detect canopy condition of deciduous broad-leaved trees. Plant Ecol Divers 4:79-89. doi:10.1080/17550874.2011.579188 
Nagai S, Saitoh TM, Kobayashi H, Ishihara M, Suzuki R, Motohka T, Nasahara KN, Muraoka H (2012) In situ examination of the relationship between various vegetation indices and canopy phenology in an evergreen coniferous forest, Japan. Int $\mathbf{J}$ Remote Sens 33:6202-6214. doi:10.1080/01431161.2012.682660

Nakazawa T, Murayama S, Tori S, Ishizawa M, Otonashi K, Aoki $\mathrm{S}$, Yamamoto S (1997) Temporal variations of the $\mathrm{CO}_{2}$ concentration and its carbon and oxygen isotopic ratios in a temperate forest in the central part of the main island of Japan. Tellus 49B:364-381. doi:10.1034/j.1600-0889.49.issue4.3.x

Nasahara KN, Nagai S (2015) Review: Development of an in situ observation network for terrestrial ecological remote sensing: the Phenological Eyes Network (PEN). Ecol Res. doi: 10.1007/s11284-014-1239-x

Nishida K (2007) Phenological Eyes Network (PEN): a validation network for remote sensing of the terrestrial ecosystems. AsiaFlux Newslett Issue 21:9-13. http://www.asiaflux.net/

Noda HM, Muraoka H, Nasahara KN, Saigusa N, Murayama S, Koizumi H (2015) Phenology of leaf morphological, photosynthetic, and nitrogen use characteristics of canopy trees in a cool-temperate deciduous broadleaf forest at Takayama, central Japan. Ecol Res. doi:10.1007/s11284-014-1222-6

Ohtsuka T, Akiyama T, Hashimoto Y, Inatomi M, Sakai T, Jia S, Mo W, Tsuda S, Koizumi H (2005) Biometric based estimates of net primary production (NPP) in a cool-temperate deciduous forest stand beneath a flux tower. Agric For Meteorol 134:27-38. doi:10.1016/j.agrformet.2005.11.005

Ohtsuka T, Mo W, Satomura T, Inatomi M, Koizumi H (2007) Biometric based carbon flux measurements and net ecosystem production (NEP) in a temperate deciduous broad-leaved forest beneath a flux tower. Ecosystems 10:324-334. doi:10.1007/s 10021-007-9017-z

Ohtsuka T, Saigusa N, Koizumi H (2009) On linking multiyear biometric measurements of tree growth with eddy covariancebased net ecosystem production. Glob Change Biol 15:1015-1024. doi:10.1111/j.1365-2486.2008.01800.x

Ohtsuka T, Shizu Y, Nishiwaki A, Yashiro Y, Koizumi H (2010) Carbon cycling and net ecosystem production at an early stage of secondary succession in an abandoned coppice forest. J Plant Res 123:393-401. doi:10.1007/s10265-009-0274-0

Ruidisch M, Nguyen TT, Li Y, Geyer R, Tenhunen J (2015) Estimation of annual spatial variations in forest production and crop yields at landscape scale in temperate climate regions. Ecol Res. doi:10.1007/s11284-014-1208-4
Saigusa N, Yamamoto S, Murayama S, Kondo H (2005) Interannual variability of carbon budget components in an AsiaFlux forest site estimated by long-term flux measurements. Agric For Meteorol 134:4-16. doi:10.1016/j.agrformet.2005.08.016

Saitoh TM, Tamagawa I, Muraoka H, Lee NY, Yashiro Y, Koizumi H (2010) Carbon dioxide exchange in a cool-temperate evergreen coniferous forest over complex topography in Japan during two years with contrasting climates. J Plant Res 123:473-483. doi:10.1007/s10265-009-0308-7

Saitoh TM, Nagai S, Saigusa N, Kobayashi H, Suzuki R, Nasahara KN, Muraoka H (2012a) Assessing the use of camerabased indices for characterizing canopy phenology in relation to gross primary production in a deciduous broad-leaved and an evergreen coniferous forest in Japan. Ecol Inform 11:45-54. doi:10.1016/j.ecoinf.2012.05.001

Saitoh TM, Nagai S, Yoshino J, Muraoka H, Saigusa N, Tamagawa I (2012b) Functional consequences of differences in canopy phenology for the carbon budgets of two cool-temperate forest types: simulations using the NCAR/LSM and validation using tower flux and biometric data. Eurasia $\mathbf{J}$ For Res 15:19-30

Saitoh TM, Nagai S, Yoshino J, Kondo H, Tamagawa I, Muraoka H (2015) Effects of canopy phenology on deciduous overstory and evergreen understory carbon budgets in a cool-temperate forest ecosystem under ongoing climate change. Ecol Res. doi: 10.1007/s11284-014-1229-Z

Tomotsune M, Yoshitake S, Masuda R, Koizumi H (2015) Preliminary observations of soil organic layers using a compact MRI for non-destructive analysis of internal soil structure. Ecol Res. doi:10.1007/s11284-015-1242-x

Yamamoto S, Koizumi H (2005) Long-term carbon exchange at Takayama site, a cool-temperate deciduous forest in Japan. Agric For Meteorol 134:1-3. doi:10.1016/j.agrformet.2005.11. 006

Yashiro Y, Lee NY, Ohtsuka T, Shizu Y, Saitoh TM, Koizumi H (2010) Biometric-based estimation of net ecosystem production in a mature Japanese cedar (Cryptomeria japonica) plantation beneath a flux tower. J Plant Res 123:463-472. doi:10.1007/s 10265-010-0323-8

Yoshitake S, Tabei N, Mizuno Y, Yoshida H, Sekine Y, Tastumura M, Koizummi H (2015) Soil microbial response to experimental warming in cool temperate semi-natural grassland in Japan. Ecol Res. doi:10.1007/s11284-014-1209-3 